DOI 10. 18307/2018. 0621

(c) 2018 by Journal of Lake Sciences

\title{
湖光岩玛珥湖水体中营养盐的时空分布特征及其影响因素”
}

\author{
陈法锦, 劳齐斌, 市培旺, 朱庆梅 ${ }^{* *}$, 周凤霞, 周 欣, 孟亚飞,王梦宇 \\ (广东海洋大学, 广东省近海海洋变化与灾害预警重点实验室, 湛江 524088)
}

\begin{abstract}
摘 要: 湖光岩玛珥湖是世界上最大的玛珥湖, 它几乎是封闭的, 受外界的干扰小. 目前有关玛珥湖的研究主要集中在古 气候及生态环境研究方面, 而有关玛珥湖营养盐在一年中的生物地球化学循环的研究较少, 因此研究湖光岩玛珥湖营养 盐的生物地球化学过程具有重要意义. 于 2015 年 10 月-2016 年 9 月对湖光岩玛珥湖全水柱的营养盐及其他相关参数进 行逐月调查, 分析营养盐的结构特征、垂直分布特征和时间变化情况, 并讨论营养盐时空变化的影响因素. 结果表明, 湖 光岩玛珥湖水中的无机氮 ( DIN) 以铵态氮 $\left(\mathrm{NH}_{4}^{+}-\mathrm{N}\right)$ 为主 $(>60 \%)$, 其次是硝态氧 $\left(\mathrm{NO}_{3}^{-}-\mathrm{N}\right)$, 亚硝态氮 $\left(\mathrm{NO}_{2}^{-}-\mathrm{N}\right)$ 所占比利 最低. 湖光岩玛珥湖水中的硅酸盐 $\left(\mathrm{SiO}_{3}^{2-}-\mathrm{Si}\right)$ 浓度较高, 水体浮游植物生长受磷限制. 冬季风期间, 水体垂直混合较均匀, 导致营养盐的垂直分布比较均匀; 夏季风期间, 水体层化, 营养盐浓度在浅层水体较低, 在深层水体较高. 湖光岩玛珥湖 表层水中的 $\mathrm{NO}_{3}^{-}-\mathrm{N} 、 \mathrm{NH}_{4}^{+}-\mathrm{N}$ 和 $\mathrm{SiO}_{3}^{2-}-\mathrm{Si}$ 具有明显的时间变化规律: $\mathrm{NO}_{3}^{-}-\mathrm{N}$ 浓度从 10 月一次年 3 月升高, 从 3-9 月降低; $\mathrm{NH}_{4}^{+}-\mathrm{N}$ 浓度从 10 月一次年 5 月降低; $\mathrm{SiO}_{3}^{2-}-\mathrm{Si}$ 浓度从 11 月一次年 5 月降低, 从 5-9 月持续升高. 营养盐浓度的时间变化 受有机质的矿化分解、水体的季节性混合、浮游植物的吸收、降雨的输人等多种因素的综合影响.
\end{abstract}

关键词: 湖光岩玛珥湖; 营养盐;垂直分布;月变化;影响因素

\section{Spatial and temporal distributions of nutrients and their influencing factors in the Huguan- gyan Maar Lake}

CHEN Fajin, LAO Qibin, BIAN Peiwang, ZHU Qingmei ${ }^{* *}$, ZHOU Fengxia, ZHOU Xin, MENG Yafei \& WANG Mengyu

(Guangdong Province Key Laboratory for Coastal Ocean Variation and Disaster Prediction Technologies, Guangdong Ocean University, Zhanjiang 524088, P.R.China)

\begin{abstract}
The Huguangyan Maar Lake is the biggest maar lake in the world. It is nearly closed and less disturbed by the surroundings. Existing work is mainly on its palaeoclimatological and the ecology environment research. The research on nutrients and their biogeochemical cycling in maar lakes is rare. Therefore, it has great significance to conduct such research in the Huguangyan Maar Lake. Nutrients and related parameters were investigated monthly in the water column of the Huguangyan Maar Lake from October 2015 to September 2016, in order to analyze the compositions, vertical distributions and temporal variations of nutrients and their influencing factors. The results showed that ammonium nitrogen $\left(\mathrm{NH}_{4}^{+}-\mathrm{N}\right)$ was the predominant speciation of dissolved inorganic nitrogen $(>60 \%)$ in the water of the Huguangyan Maar Lake, followed by nitrate nitrogen $\left(\mathrm{NO}_{3}^{-}-\mathrm{N}\right)$, and nitrite nitrogen $\left(\mathrm{NO}_{2}^{-}-\mathrm{N}\right)$ was the lowest speciation. The concentrations of silicate $\left(\mathrm{SiO}_{3}^{2-}-\mathrm{Si}\right)$ were relatively high, while phosphorus was the limiting nutrient for phytoplankton growth in the Huguangyan Maar Lake. During the winter monsoon, the concentrations of nutrients were vertically stable due to the enhanced vertical mixing. While during the summer monsoon, the water column stratified and nutrients in shallow water were generally low and deep water higher. Monthly variations of $\mathrm{NO}_{3}^{-}-\mathrm{N}, \mathrm{NH}_{4}^{+}-\mathrm{N}$ and $\mathrm{SiO}_{3}^{2-}-\mathrm{Si}$ showed obvious variation patterns. Concentrations of $\mathrm{NO}_{3}^{-}-\mathrm{N}$ increased from October to March but decreased from March to September; concentrations of $\mathrm{NH}_{4}^{+}-\mathrm{N}$ decreased from October to May; and concentrations of $\mathrm{SiO}_{3}^{2-}-\mathrm{Si}$ decreased from November to May and increased from May to Sep-
\end{abstract}

* 国家自然科学基金项目 (41476066, 41476010,41403003)、广东省自然科学基金项目 (2016A030312004)、广东省 高等学校优秀青年教师培养计划项目 (Yq2014004) 和广东海洋大学创新强校项目 (GDOU2014050201) 联合资助. 2018-01-29 收稿;2018-03-20 收修改稿. 陈法锦( 1981 ), 男,博士, 副教授;E-mail:fjchen04@ 163.com.

** 通信作者;E-mail : zhuqingmei1987@ 163.com. 
tember. Their temporal variations were influenced by combined factors of organic matter decomposition, seasonal water-column mixing, phytoplankton absorption, rain-induced inputs and so on.

Keywords: Huguangyan Maar Lake; nutrients; vertical distributions; monthly change; influencing factor

氮、磷、硅等营养元素是湖泊生态系统的重要物质基础, 浮游植物能通过光合作用吸收营养盐, 合成有 机质 ${ }^{[1-2]}$. 湖泊中营养盐浓度、结构状况以及营养盐的可获取性对湖泊生物的生产力起着控制作用 ${ }^{[3-4]}$. 近年 来,随着社会经济的飞速发展、人口的剧烈增加以及水资源的不合理开发利用,湖泊的富营养化情况日益严 重,这一现象已经受到国内外研究者的重视 ${ }^{[5-9]}$.

湖光岩玛珥湖是由平地火山爆发后冷却下沉形成的玛珥式火山湖, 是一个典型的亚热带天然湖泊. 湖光 岩玛珥湖几乎是封闭的, 没有出人水口, 受外界的干扰极小, 水体稳定且滞留时间长 ${ }^{[10]}$. 目前, 有关玛珥湖的研 究主要集中在沉积与环境方面, 研究区域主要集中在欧洲 ${ }^{[11-13]}$, 有关玛珥湖营养盐生物地球化学过程的研究 较少. 已有的相关研究大多停留在对某一季节或长时间段表层水的生态环境特征分析上, 缺乏对整个水柱生 态环境长时间变化的研究 ${ }^{[10,14-16]}$. 如张国维 ${ }^{[10]}$ 通过对春季湖光岩玛珥湖浮游植物群落氮吸收及其吸收动力学 特征的研究, 发现湖光岩玛珥湖浮游植物群落对铵态氮具有较高的吸收潜力, 并且对硝态氮具有一定的亲和 力, 具备利用硝态氮的能力. 郭倩茹 ${ }^{[15]}$ 通过对夏季湖光岩玛珥湖水中浮游细菌的研究, 发现该湖泊中的细菌群 落类型与其他淡水湖泊基本相同, 而同一类别的细菌群落所占的百分比与其他湖泊有所差异. 张国维等 ${ }^{[16]}$ 于 2013 年 1- 12 月对湖光岩玛珥湖表层水的叶绿素 a (Chl.a) 及相关环境因子进行逐月调查, 发现氮、磷共同限 制浮游植物生长. 因此, 本文基于 2015 年 10 月至 2016 年 9 月对湖光岩玛珥湖全水柱的营养盐、Chl.a、溶解氧 等参数的逐月调查结果, 分析营养盐在湖光岩玛珥湖整个水柱中的结构组成情况、空间分布情况及时间变化 情况, 并结合相关环境因子讨论湖光岩玛珥湖营养盐的时空变化原因. 这一研究对于认识湖光岩玛珥湖营养 盐的生物地球化学过程有重要意义,同时也为湖光岩玛珥湖的生态环境保护提供科学依据.

\section{1 材料与方法}

\section{1 采样区域及站点布设}

湖光岩玛珥湖 $\left(21^{\circ} 09^{\prime} \mathrm{N}, 110^{\circ} 17^{\prime} \mathrm{E}\right)$ 位于广东省湛江市西南区, 在大约 16 万年前玛珥火山爆发冷却后由 地下矿质水和雨水形成, 是世界上最大且保存最完整的玛珥湖, 也是中国玛珥湖研究的始发点以及世界玛 珥湖研究的关键点. 湖光岩玛珥湖没有河流输人与输出, 几乎不受外界水系统干扰, 湖水变化主要取决于大 气降水和地下水的变化 ${ }^{[10,14]}$. 该湖分为东、西两湖, 东湖较小且较浅, 西湖较大且较深, 湖的总面积为 2.3 $\mathrm{km}^{2}$, 最深处约为 $22 \mathrm{~m}$. 湖光岩地处北回归线以南的热带边缘, 属于热带季风气候 (冬季风: 10 月一次年 3 月, 夏季风: 4-9 月), 夏季长冬季短, 具有明显的雨季和旱季. 湖光岩玛珥湖夏季受西南季风的影响, 冬季受东 北季风的影响, 另外还经常受到热带风暴的影响. 湖光岩玛珥湖四周为火山碎屑岩岩墙, 区域植被主要为半 常绿雨林, 土壤木质主要为火山碎屑岩化残积层 ${ }^{[17]}$.

于 2015 年 10 月至 2016 年 9 月的每月月底在湖光岩玛珥湖采集水样, 采样站点如图 1 所示. 根据湖光 岩的特征, 总共设置 5 个采样点. 其中 H02 和 H03 位于湖东侧, H04 和 H05 位于湖西侧, H01 位于西大湖和 东小湖的交界处. 采样层次根据水体深度设置为表层(离水面 $0.5 \mathrm{~m}$ ) 、 $2 \mathrm{~m} 、 5 \mathrm{~m} 、 8 \mathrm{~m} 、 10 \mathrm{~m} 、 12 \mathrm{~m}$ 和底层(离 水底约 $1 \mathrm{~m}$ ), 具体采样层次根据不同站点的具体水深而定. 每个航次的采样站位和采样层次基本一致.

\section{2 样品采集与测定}

现场用加拿大 RBR 公司的 RBRmaestro 快速多参数水质仪测定水体的深度、温度和 $\mathrm{pH}$. 用 Niskin 采水 器采集不同深度的水样, 水样用于营养盐 (包括硝态氮 $\left(\mathrm{NO}_{3}^{-}-\mathrm{N}\right)$ 、亚硝态氮 $\left(\mathrm{NO}_{2}^{-}-\mathrm{N}\right)$ 、铵态氮 $\left(\mathrm{NH}_{4}^{+}-\mathrm{N}\right)$ 、磷酸 盐 $\left(\mathrm{PO}_{4}^{3-}-\mathrm{P}\right)$ 和硅酸盐 $\left(\mathrm{SiO}_{3}^{2-}-\mathrm{Si}\right)$ )、溶解氧 $(\mathrm{DO})$ 和 $\mathrm{Chl} . \mathrm{a}$ 浓度的分析. 用采水器采集水样后, 先收集两瓶体积 约 $120 \mathrm{ml}$ 的水样用于 DO 浓度的分析, 之后收集用于营养盐和 Chl.a 浓度分析的水样. 用于营养盐分析的水 样采集后立即用洗净的 $0.45 \mu \mathrm{m}$ 醋酸纤维膜过滤, 过滤后的水样装于 $30 \mathrm{ml}$ 的聚乙烯瓶中 ( 聚乙烯瓶预先用 $30 \%$ 的盐酸浸泡 $24 \mathrm{~h}$, 然后用超纯水冲洗到中性), 冷冻保存 $\left(-20^{\circ} \mathrm{C}\right)$, 待测. 用于 Chl.a 分析的水样现场用 玻璃纤维膜 (Whatman GF/F) 过滤. 将过滤后得到的玻璃纤维滤膜对折, 用锡纸包裹、冷冻保存, 带回实验室 


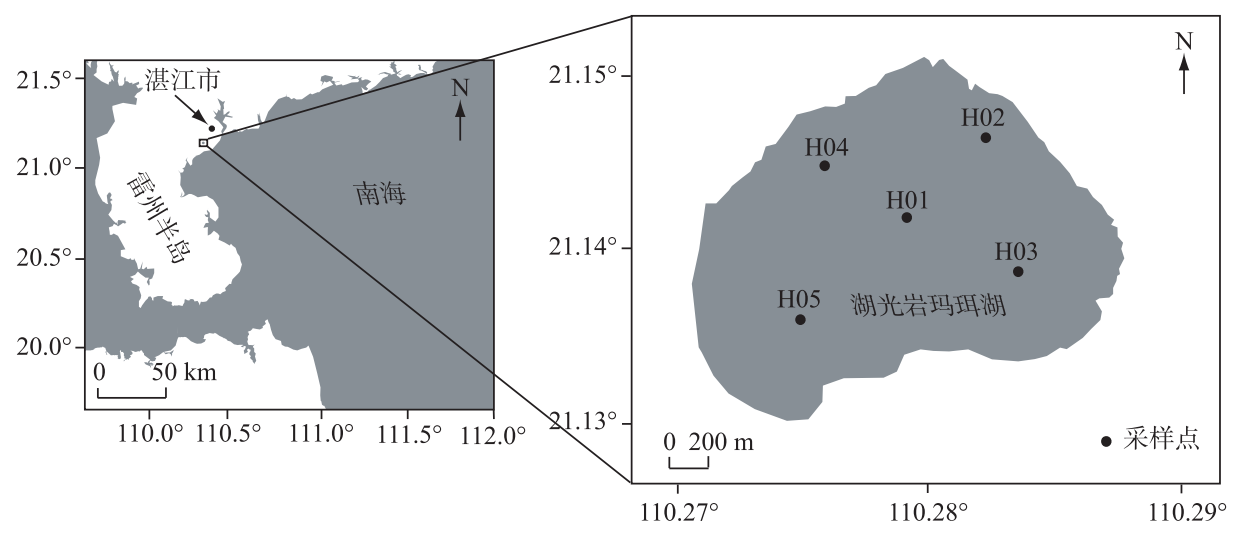

图 1 湖光岩玛珥湖采样站位分布

Fig.1 The distribution of sampling stations of the Huguangyan Maar Lake

进行分析测定. 此外, 对调查期间湖光岩玛珥湖的降雨量进行了监测, 监测点位于湖光岩玛珥湖附近 $500 \mathrm{~m}$ 处, 对湖光岩玛珥湖附近降雨量的监测可以反映湖光岩玛珥湖的降雨量情况. 采集降雨所用的采雨器直径 为 $60 \mathrm{~cm}$, 降雨之前打开, 结束后立即取回, 测量降雨量.

$\mathrm{NO}_{2}^{-}-\mathrm{N} 、 \mathrm{NO}_{3}^{-}-\mathrm{N}+\mathrm{NO}_{2}^{-}-\mathrm{N} 、 \mathrm{PO}_{4}^{3-}-\mathrm{P} 、 \mathrm{SiO}_{3}^{2-}-\mathrm{Si}$ 和 $\mathrm{NH}_{4}^{+}-\mathrm{N}$ 浓度的测定依据《湖泊富营养化调查规范》 ${ }^{[18]}$ 和《水 和废水监测分析方法 $\rangle^{[19]}$ 中的方法测定. DO 浓度采用 Winkler 碘量法进行现场测 ${ }^{\text {定 }}{ }^{[19]}$. Chl. a 浓度采用苂 光分光光度法测定 ${ }^{[20]} . \mathrm{NO}_{2}^{-}-\mathrm{N}$ 通过重氮偶氮比色法直接测出准确浓度, $\mathrm{NO}_{3}^{-}-\mathrm{N}$ 由于不能直接显色, 需要通 过 $\mathrm{Cd}-\mathrm{Cu}$ 还原转化为 $\mathrm{NO}_{2}^{-}-\mathrm{N}$ 后经重氮偶氮法准确测出 $\mathrm{NO}_{2}^{-}-\mathrm{N}$ 浓度, 实际是 $\mathrm{NO}_{3}^{-}-\mathrm{N}+\mathrm{NO}_{2}^{-}-\mathrm{N}$ 的总浓度, 所以 $\mathrm{NO}_{3}^{-}-\mathrm{N}$ 浓度为测得 $\mathrm{NO}_{3}^{-}-\mathrm{N}+\mathrm{NO}_{2}^{-}-\mathrm{N}$ 浓度减去 $\mathrm{NO}_{2}^{-}-\mathrm{N}$ 浓度. 溶解无机氮 $(\mathrm{DIN})=\mathrm{NO}_{3}^{-}-\mathrm{N}+\mathrm{NO}_{2}^{-}-\mathrm{N}+\mathrm{NH}_{4}^{+}-\mathrm{N}$.

\section{2 结果与讨论}

\section{1 湖光岩玛珥湖水体环境的基本特征}

所调查站位中水体深度的变化范围为 $2.5 \sim 16.8 \mathrm{~m}$,最小值出现在 2015 年 10 月的 $\mathrm{H} 02$ 站位 $(2.5 \mathrm{~m})$, 最 大值出现在 2016 年 9 月的 H01 站位 (16.8 m). 调查期间, 各站位水体深度的变化范围基本小于 $3 \mathrm{~m}(\mathrm{H} 01$ : 15.0 16.8 m; H02:2.5 4.5 m ; H03:8.0 8.9 m ; H04:9.0 10.9 m; H05:13.0 16.0 m), 且在降雨量较大的 夏季水体较深. 不同站位同一水层的温度在同一时间段的空间分布差异较小,且不同站位同一水层温度的 时间变化趋势相近. H02 和 H03 站位水体较浅 $(<9 \mathrm{~m})$, 水体温度在全年均没有出现分层; H01、H04 和 H05 站位水体较深 $(>10 \mathrm{~m})$, 水体温度在 3-9 月出现层化, 在其他月份水体垂直混合较均匀. 不同站位水体温度 的时间变化趋势相近, 均从 10 月一次年 2 月逐渐降低, 2-6月逐渐升高, 浅层水体 $(<5 \mathrm{~m})$ 温度在 7-9 月略 有降低, 深层水体 $(>8 \mathrm{~m})$ 温度总体在 7-9 月呈升高趋势. 以 H01 站位为例, H01 站位水深约 $16 \mathrm{~m}$, 该站位 水体温度的时空变化情况为: 2 月的水体温度最低 (水柱平均温度为 $16.0^{\circ} \mathrm{C}$ ), 12 月表、底层水体温差最小 (表、底层水体温差为 $0.04^{\circ} \mathrm{C}$ ); 9 月的水体温度最高 (水柱平均温度为 $27.2^{\circ} \mathrm{C}$ ), 6 月的表、底层水体差最大 (表、底层水体温差为 $14.6^{\circ} \mathrm{C}$ ) (图 2, $\mathrm{H} 01$ ).

与温度的时空变化相近, 其他参数在不同站位同一水层的空间分布差异较小, 且它们在不同站位同一 水层的时间变化趋势相近, 为了压缩图数量, 后文中的部分参数仅用 H01 和 H02 两个具有代表性的站位来 表征它们的时空分布情况. 湖光岩玛珥湖水体 $\mathrm{pH}$ 的变化范围为 6.85 8.44, 在冬季风期间垂直分布较均匀, 在夏季风期间出现层化, 深层水体 $(>10 \mathrm{~m})$ 的 $\mathrm{pH}$ 普遍低于浅层水体 $(<10 \mathrm{~m})$. 湖光岩玛珥湖水体中 Chl.a 浓度的变化范围为 $0.89 \sim 5.60 \mu \mathrm{g} / \mathrm{L}$, 这一范围与张国维等 ${ }^{[16]}$ 于 2013 年对湖光岩玛珥湖表层水体 Chl.a 浓度 的调查结果相当 $(1.08 \sim 4.22 \mu \mathrm{g} / \mathrm{L})$. 本研究也对湖光岩玛珥湖 Chl. a 浓度的垂直分布进行分析, 发现 Chl.a 在冬季的全水柱以及夏季的深层水中 $(>10 \mathrm{~m})$ 具有较高的浓度, 在夏季的浅层水体 $(<10 \mathrm{~m})$ 具有相对较低 
$\square-0.5 \mathrm{~m}-\triangle-2 \mathrm{~m} \rightarrow-5 \mathrm{~m}-\mathrm{o}-8 \mathrm{~m} \approx 10 \mathrm{~m}+12 \mathrm{~m} * 14 \mathrm{~m}$
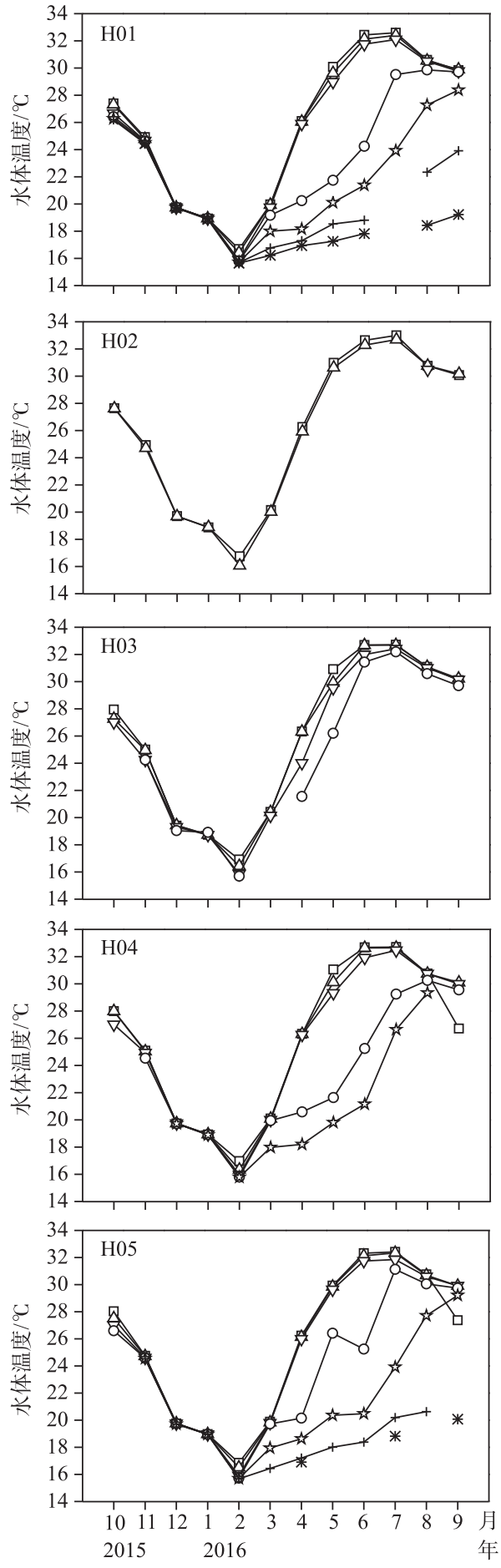

图 2 不同月份湖光岩玛珥湖 水体温度的垂直分布情况

Fig. 2 The vertical distribution of water temperature in the Huguangyan Maar Lake in different months
的浓度. 湖光岩玛珥湖水中 DO 浓度的变化范围为 $2.21 \sim 11.38 \mathrm{mg} / \mathrm{L}$, 它在夏季的深层水体 $(>10 \mathrm{~m})$ 具 有较低的浓度. 综合水体温度、pH、Chl. a 浓度和 DO 浓度的分布情况可知, 湖光岩玛珥湖在冬季水体混 合较均匀,垂直变化都较小; 在夏季, 浅层水体升温, 水体层化明显, 导致温度、pH、Chl.a 浓度和 DO 浓度 的垂直变化都较大. 夏季浅层水体的营养盐由于水 体层化而得不到有效补充, 导致浅层水体的 Chl.a 浓 度较低, 深层水体由于沉积物有机质矿化产生较多 的营养盐从而导致深层水体的 Chl.a 浓度较高 (营养 盐的分析内容见后文). 虽然没有沉积物有机质的相 关数据,但可由夏季深层水体的 $\mathrm{DO}$ 浓度和 $\mathrm{pH}$ 值都 较低,推断出有机质氧化分解消耗了较多的氧气并 产生了较多的二氧化碳. 后文中有关营养盐的分析 也支持这一推论.

\section{2 岩玛珥湖水体中营养盐的地球化学特征}

2.2.1 湖光岩玛珥湖营养盐的浓度和结构特征 2015 年 10 月至 2016 年 9 月湖光岩玛珥湖水体中溶解态 营养盐浓度及组成特征见表 1. 表层和底层水中的 DIN 均以 $\mathrm{NH}_{4}^{+}-\mathrm{N}$ 浓度最高, 占 DIN 浓度的 $60 \%$ 以上, $\mathrm{NO}_{3}^{-}-\mathrm{N}$ 比例次之, $\mathrm{NO}_{2}^{-}-\mathrm{N}$ 比例最低 $(<2 \%$ ) (表 1). 底 层水中 $\mathrm{NO}_{3}^{-}-\mathrm{N} 、 \mathrm{NO}_{2}^{-}-\mathrm{N}$ 和 $\mathrm{NH}_{4}^{+}-\mathrm{N}$ 的浓度平均值分别 为表层的 $1.26 、 4.0$ 和 1.44 倍 (表 1 ), 表明底层水中 各形态的 DIN 浓度均明显高于表层. 底层水中 $\mathrm{NH}_{4}^{+}-\mathrm{N}$ 浓度占 DIN 浓度的比例 ( 70\%) 略高于表层 (68\%)（表 1), 若仅考虑夏季风期间水体分层较明 显的 H01 和 H05 站位的表层和底层水, 发现底层水 中 $\mathrm{NH}_{4}^{+}-\mathrm{N}$ 占 DIN 的比例 $(69 \%)$ 明显高于表层 $(59 \%)$ (表 1). 这可能说明深层水体或表层沉积物有 机质的降解对 DIN 的组成情况产生了影响. 夏季水体 层化明显, 深层水体 $(>10 \mathrm{~m}$ ) 的 DO 浓度较低 (图 2, 图 4). 这说明深层水体或表层沉积物的有机质降解耗氧 明显, 导致较多的 $\mathrm{NH}_{4}^{+}-\mathrm{N}$ 产生, 因而导致水体层化明 显的区域底层水中 $\mathrm{NH}_{4}^{+}-\mathrm{N}$ 的比例高于表层水.

湖光岩水体中 $\mathrm{SiO}_{3}^{2-}-\mathrm{Si}$ 浓度处于较高水平, 表层 和底层水中 $\mathrm{SiO}_{3}^{2-}-\mathrm{Si}$ 浓度范围分别为 $0.379 \sim 0.840$ 和 $0.435 \sim 1.139 \mathrm{mg} / \mathrm{L}$, 它是 3 种营养元素中浓度最 高的营养盐 (表 1). 这可能是因为湖光岩玛珥湖四 面为火山岩, 火山岩含有丰富的 $\mathrm{Si}$ 元素, 降雨可能导 致岩石、土壤风化产生的颗粒及可溶解的物质随雨 水冲刷, 进而导致较高浓度的 $\mathrm{SiO}_{3}^{2-}-\mathrm{Si}$ 进人湖光岩水 体. $\mathrm{PO}_{4}^{3-}-\mathrm{P}$ 浓度处于较低水平, 它在表层和底层水体 中的浓度都较低 (表 1 ). 湖光岩水体中较低浓度的 $\mathrm{PO}_{4}^{3-}-\mathrm{P}$ 可能与浮游植物对营养盐的吸收有关. 春季、 

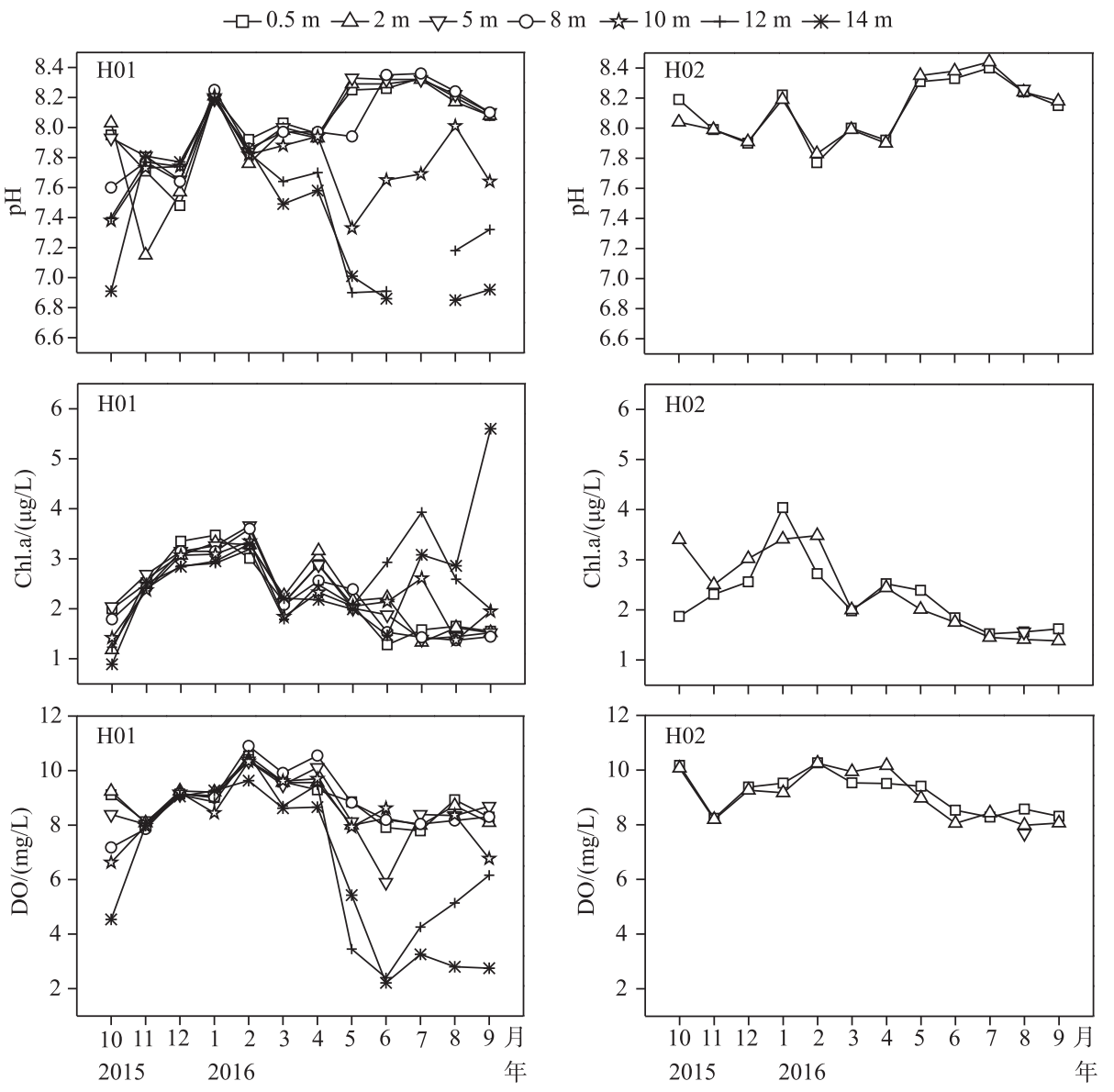

图 3 不同月份湖光岩玛珥湖水体中 $\mathrm{pH} 、 \mathrm{Chl}$. a 浓度和 $\mathrm{DO}$ 浓度的垂直分布情况

Fig.3 The vertical distributions of $\mathrm{pH}$, Chl.a and DO concentrations in the water of the Huguangyan Maar Lake in different months

表 1 采样期间湖光岩玛珥湖水体中溶解态营养盐浓度和结构特征 *

Tab.1 The concentrations and compositions of dissolved nutrients in the water of the Huguangyan Maar Lake during the sampling period

\begin{tabular}{ccccc}
\hline 营养盐 & 表层 & 表层平均值 & 底层 & 底层平均值 \\
\hline $\mathrm{NO}_{3}^{-}-\mathrm{N} /(\mathrm{mg} / \mathrm{L})$ & $0.0049 \sim 0.071$ & 0.031 & $0.0049 \sim 0.137$ & 0.039 \\
$\mathrm{NO}_{2}^{-}-\mathrm{N} /(\mathrm{mg} / \mathrm{L})$ & $0.0001 \sim 0.0010$ & 0.0006 & $0.0001 \sim 0.0309$ & 0.0022 \\
$\mathrm{NH}_{4}^{+}-\mathrm{N} /(\mathrm{mg} / \mathrm{L})$ & $0.0022 \sim 0.185$ & 0.064 & $0.0014 \sim 0.298$ & 0.092 \\
$\mathrm{DIN} /(\mathrm{mg} / \mathrm{L})$ & $0.013 \sim 0.206$ & 0.094 & $0.013 \sim 0.312$ & 0.133 \\
$\mathrm{SiO}_{3}^{2-}-\mathrm{Si} /(\mathrm{mg} / \mathrm{L})$ & $0.379 \sim 0.840$ & 0.563 & $0.435 \sim 1.139$ & 0.632 \\
$\mathrm{PO}_{4}^{3-}-\mathrm{P} /(\mathrm{mg} / \mathrm{L})$ & $\mathrm{ND} \sim 0.0009$ & 0.0006 & $\mathrm{ND} \sim 0.0009$ & 0.0003 \\
$\mathrm{~N}: \mathrm{P}$ & $87 \sim 1473$ & 571 & $49 \sim 2225$ & 746 \\
$\mathrm{Si}: \mathrm{P}$ & $534 \sim 3000$ & 1561 & $562 \sim 4068$ & 1788 \\
$\mathrm{Si}: \mathrm{N}$ & $1.44 \sim 23.1$ & 4.87 & $1.25 \sim 27.8$ & 4.52 \\
\hline
\end{tabular}

* ND 表示低于检测限. 
夏季和秋季, 湖光岩水体中的浮游植物以蓝藻和绿藻为主 ${ }^{[14]}$, 蓝藻和绿藻对 $\mathrm{P}$ 的需求较大, 对 $\mathrm{Si}$ 则无明显 需求, 水体中的 $\mathrm{P}$ 被浮游植物大量的消耗可能是湖光岩水体中磷浓度较低的主要原因.

根据 Justic 等 ${ }^{[21]}$ 的营养盐限制状况判断标准: 当水体中 $\mathrm{N}: \mathrm{P}$ 和 $\mathrm{Si}: \mathrm{P}$ 都大于 22 时为 $\mathrm{P}$ 限制 ( $\mathrm{N}=\mathrm{DIN}$, $\left.\mathrm{P}=\mathrm{PO}_{4}^{3-}-\mathrm{P}\right)$; 当 $\mathrm{N}: \mathrm{P}$ 小于 10 和 $\mathrm{Si}: \mathrm{N}$ 大于 1 时为 $\mathrm{N}$ 限值 $\left(\mathrm{Si}=\mathrm{SiO}_{3}^{2-}-\mathrm{Si}\right)$; 当 $\mathrm{Si}: \mathrm{P}$ 小于 10 和 $\mathrm{Si}: \mathrm{N}$ 小于 1 时为 $\mathrm{Si}$ 限制. 本研究中, 湖光岩玛珥湖表层和底层水的 $\mathrm{N}: \mathrm{P}$ 范围分别为 $87 \sim 1473$ 和 $49 \sim 2225, \mathrm{Si}: \mathrm{N}$ 范围分别为 $1.44 \sim 23.1$ 和 $1.25 \sim 27.8, \mathrm{Si}: \mathrm{P}$ 范围分别为 $534 \sim 3000$ 和 $562 \sim 4068$, 其中 $\mathrm{N}: \mathrm{P}$ 和 $\mathrm{Si}: \mathrm{P}$ 均远高于22(表 1 ), 表 现为较强的 P 限制. 这一分析结果与前人对湖光岩玛珥湖的研究结果一致 ${ }^{[16]}$. 需要注意的是, 随着湖光岩 周边人为影响的加大, 一旦短期内有大量的 $\mathrm{PO}_{4}^{3-}-\mathrm{P}$ 输人, 将很可能导致湖光岩玛珥湖的水体发生水华 ${ }^{[7]}$.

2.2.2 湖光岩玛珥湖营养盐的垂直分布随时间的变化情况 图 4 到图 7 为所调查的湖光岩玛珥湖 5 个站位 不同层次水体中营养盐的时间变化情况. 总体而言, 不同站位相同水层中营养盐浓度的时间变化趋势一致. 所调查的 5 个站位的水柱中 $\mathrm{NO}_{3}^{-}-\mathrm{N}$ 浓度均在 2 月和 3 月较高、在 7-9 月较低 (图 4a), 如 $\mathrm{H} 01$ 站位 3 月水柱 中 $\mathrm{NO}_{3}^{-}-\mathrm{N}$ 平均浓度 $\left(0.071 \mathrm{mg} / \mathrm{L}\right.$ ) 为 9 月 $\left(0.011 \mathrm{mg} / \mathrm{L}\right.$ ) 的 6.5 倍 (图 $4 \mathrm{a}, \mathrm{H} 01$ ). 在 $4-7$ 月 $\mathrm{NO}_{3}^{-}-\mathrm{N}$ 浓度在 3 个 水体较深的站位 (H01、H04 和 H05) 出现分层, 表现为深层水体浓度较高, 浅层水体浓度较低. 以 5 月 $\mathrm{H} 01$ 站 位的水体为例, 深层水体 $(\geqslant 10 \mathrm{~m})$ 中 $\mathrm{NO}_{3}^{-}-\mathrm{N}$ 浓度为浅层水体 $(<10 \mathrm{~m})$ 的 3.2 倍. 在其他月份, 较深站位的 $\mathrm{NO}_{3}^{-}-\mathrm{N}$ 浓度的垂直变化不是很明显, 主要原因可能是这些时间段水体垂直混合均匀或浮游植物对浅层和深 层水体的营养盐都利用较多. 湖光岩玛珥湖位于亚热带季风气候区, 10 月一次年 3 月盛行冬季风, $4-9$ 月盛 行夏季风. 在冬季风盛行期间, 水体温度较低, 水体垂直对流混合加强 (图 2, H01 和 H05), 导致该时间段 $\mathrm{NO}_{3}^{-}-\mathrm{N}$ 浓度的垂直变化不是很明显 (图 4a, H01 和 H05) ; 在 7-9 月水体较深的站位层化明显 (图 2), 由于 浅层水体的营养盐消耗殆尽 (图 4a, H01 和 H05), 浮游植物倾向于利用深层水体的营养盐, 从而导致该时间 段深层水体的 $\mathrm{NO}_{3}^{-}-\mathrm{N}$ 浓度也较低 (图 4a, $\mathrm{H} 01$ 和 $\mathrm{H} 05$ ). 在水深较浅的 $\mathrm{H} 02$ 和 $\mathrm{H} 03$ 站位, $\mathrm{NO}_{3}^{-}-\mathrm{N}$ 浓度的层化 现象在全年都不太明显, 主要原因是水体较浅, 再加上季风的影响, 这些水深较浅的区域水体混合相对较均 匀(图 2).

湖光岩玛珥湖浅层水体中 $\mathrm{NO}_{2}^{-}-\mathrm{N}$ 浓度在全年都较低 $(<0.01 \mathrm{mg} / \mathrm{L})\left(\right.$ 图 4b), 这一结果与张国维等 ${ }^{[16]}$ 在 2013 年对湖光岩玛珥湖表层水中 $\mathrm{NO}_{2}^{-}-\mathrm{N}$ 浓度的调查结果一致. 而在 4-5 月 2 个水体较深的站位 ( $\mathrm{H} 01$ 和 $\mathrm{H} 05)$ 的深层水 $\left(>10 \mathrm{~m}\right.$ ) 中, $\mathrm{NO}_{2}^{-}-\mathrm{N}$ 浓度达到了 $0.03 \mathrm{mg} / \mathrm{L}$ ( 图 4b), 主要原因是深层水体发生了反硝化反应. 在 4-6 月湖光岩玛珥湖水体出现层化, 水体较深的站位表、底层温差增大 (图 $2 \mathrm{H} 01$ 和 H05), 同时湖光岩玛 珥湖深层水体的溶解氧浓度明显降低, 由 4 月的 $8 \mathrm{mg} / \mathrm{L}$ 降低到 6 月的 $2 \mathrm{mg} / \mathrm{L}$ (图 3), 深层水体的 $\mathrm{pH}$ 也从 4 月的 7.6 降低到了 6 月的 6.8 (图 3). 这些情况说明, 在这一时间段深层水体中, 有机物消耗氧气进行分解, 产生了较多的二氧化碳, 导致 $\mathrm{pH}$ 降低, 水体层化导致深层水体的溶解氧得不到有效补充. Zhou 等 ${ }^{[22]}$ 通过实 验室模拟培养发现, 在溶解氧浓度较低的条件下, 水中 $\mathrm{NO}_{2}^{-}-\mathrm{N}$ 浓度会增加. 因此推断, 湖光岩玛珥湖深层水 体 $\mathrm{NO}_{2}^{-}-\mathrm{N}$ 浓度在 4-5 月较高的原因是: 该时间段, 深层水体有机质消耗氧气进行分解, 但由于水体较深的 站位水体出现层化, 导致深层水体的溶解氧得不到有效补充, 溶解氧浓度明显降低, 因而导致有较多的 $\mathrm{NO}_{2}^{-}-\mathrm{N}$ 产生. 不同站位浅层水体 $(<10 \mathrm{~m})$ 中 $\mathrm{NH}_{4}^{+}-\mathrm{N}$ 浓度的时间变化情况相似, 均为冬季风期间较高, 夏季风 期间较低( 图 5a;ANOVA: $P<0.05$ ). 深层水 ( $>10 \mathrm{~m}$ ) 中 $\mathrm{NH}_{4}^{+}-\mathrm{N}$ 浓度在 4-8 月出现相对较高值 (图 5a, H01 和 H05), 这可能与水体层化以及有机质降解有关. 在 4-8 月水体较深的站位层化明显 (图 2), 深层水中溶 解氧浓度较低 (图 3), 说明深层水体或沉积物中有机质降解耗氧明显, 因而产生了较多的 $\mathrm{NH}_{4}^{+}-\mathrm{N}$.

所调查站位中 $\mathrm{PO}_{4}^{3-}-\mathrm{P}$ 浓度普遍较低, 没有表现出明显的时空变化特征 (图 5b), 较低浓度的 $\mathrm{PO}_{4}^{3-}-\mathrm{P}$ 可 能与浮游植物充分吸收利用有关. 浅层水体 $(<10 \mathrm{~m})$ 中 $\mathrm{SiO}_{3}^{2-}-\mathrm{Si}$ 浓度在 9 月一次年 1 月较高, 在 $2-8$ 月较低 (图 6). 在夏季风期间 (4-9 月), 水体层化明显的时间段 (图 2), 深层水体的 $\mathrm{SiO}_{3}^{2-}-\mathrm{Si}$ 浓度较高 (图 6, $\mathrm{H} 01$ 和 $\mathrm{H} 05$ ), 这可能与有机质的氧化分解有关. 在冬季风期间 (10 月一次年 3 月), $\mathrm{SiO}_{3}^{2-}-\mathrm{Si}$ 浓度的垂直分布变化 不大,这主要是因为该时间段水体对流混合较强,垂直混合较均匀(图 2).

综上, 冬季风期间 ( 10 月一次年 3 月), 浅层水温降低, 上下层水体温差变小 $\left(<4^{\circ} \mathrm{C}\right.$ ), 温跃层被破坏, 水 体垂直混合较均匀 (图 2), 使得该时间段营养盐的垂直分布相对较均匀 (图 4 图 6). 冬季 (12 月一次年 2 月), 大部分营养盐浓度相对较高 (图 4 图 6), 温度适宜 $\left(15 \sim 27^{\circ} \mathrm{C}\right.$, 图 2 ), 导致该时间段浮游植物的浓度较 
$\neg-0.5 \mathrm{~m}-\triangle 2 \mathrm{~m}-\nabla-5 \mathrm{~m}-\mathrm{O}-8 \mathrm{~m} \rightarrow 10 \mathrm{~m}+12 \mathrm{~m} * 14 \mathrm{~m}$

(a)
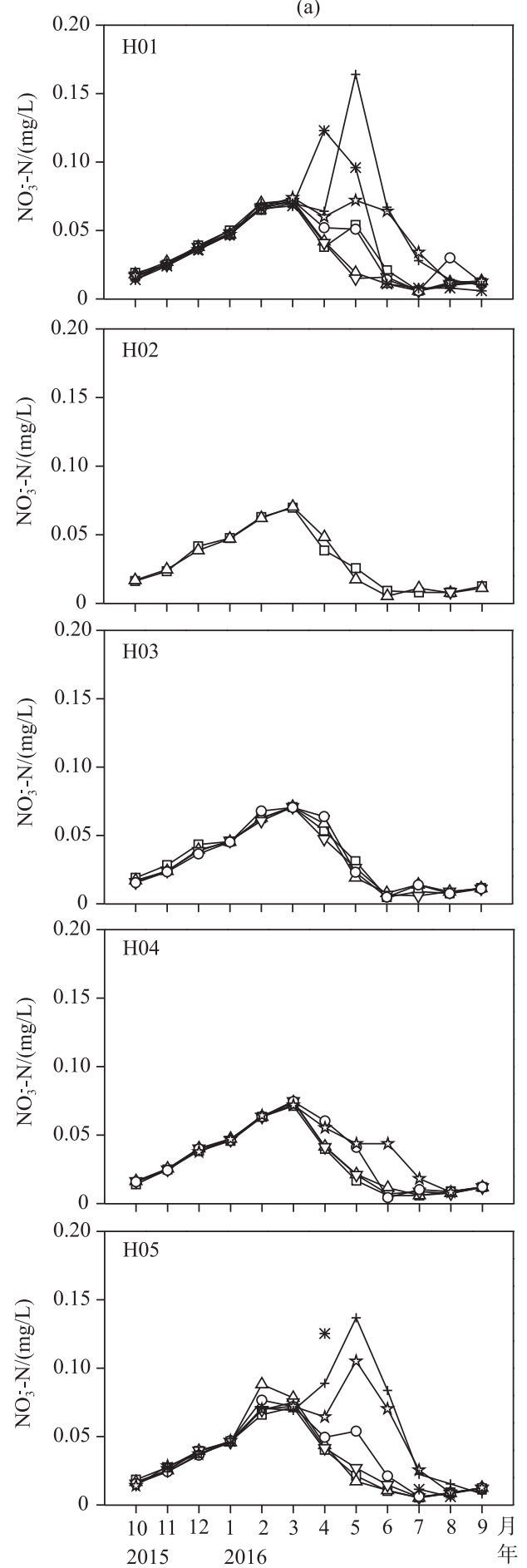

(b)
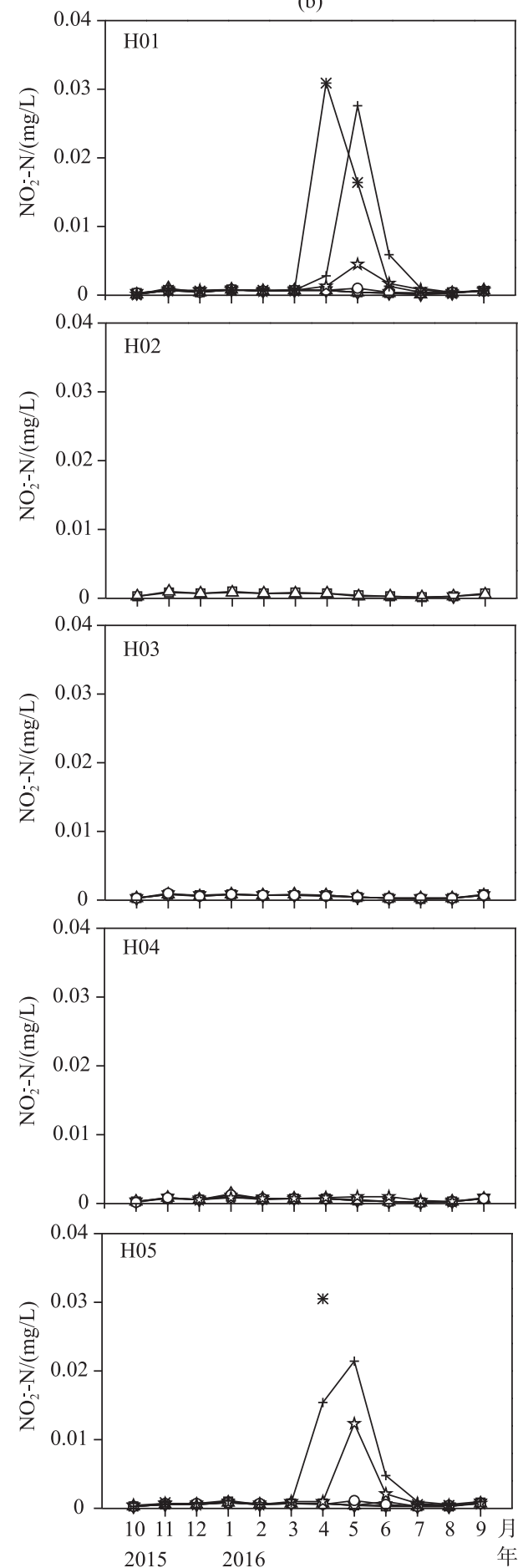

图 4 不同月份湖光岩玛珥湖水体中 $\mathrm{NO}_{3}^{-}-\mathrm{N}(\mathrm{a})$ 和 $\mathrm{NO}_{2}^{-}-\mathrm{N}(\mathrm{b})$ 浓度的垂直分布情况

Fig.4 The vertical distribution of $\mathrm{NO}_{3}^{-}-\mathrm{N}$ ( a ) and $\mathrm{NO}_{2}^{-}-\mathrm{N}$ (b) concentrations in the water of the Huguangyan Maar Lake in different months 

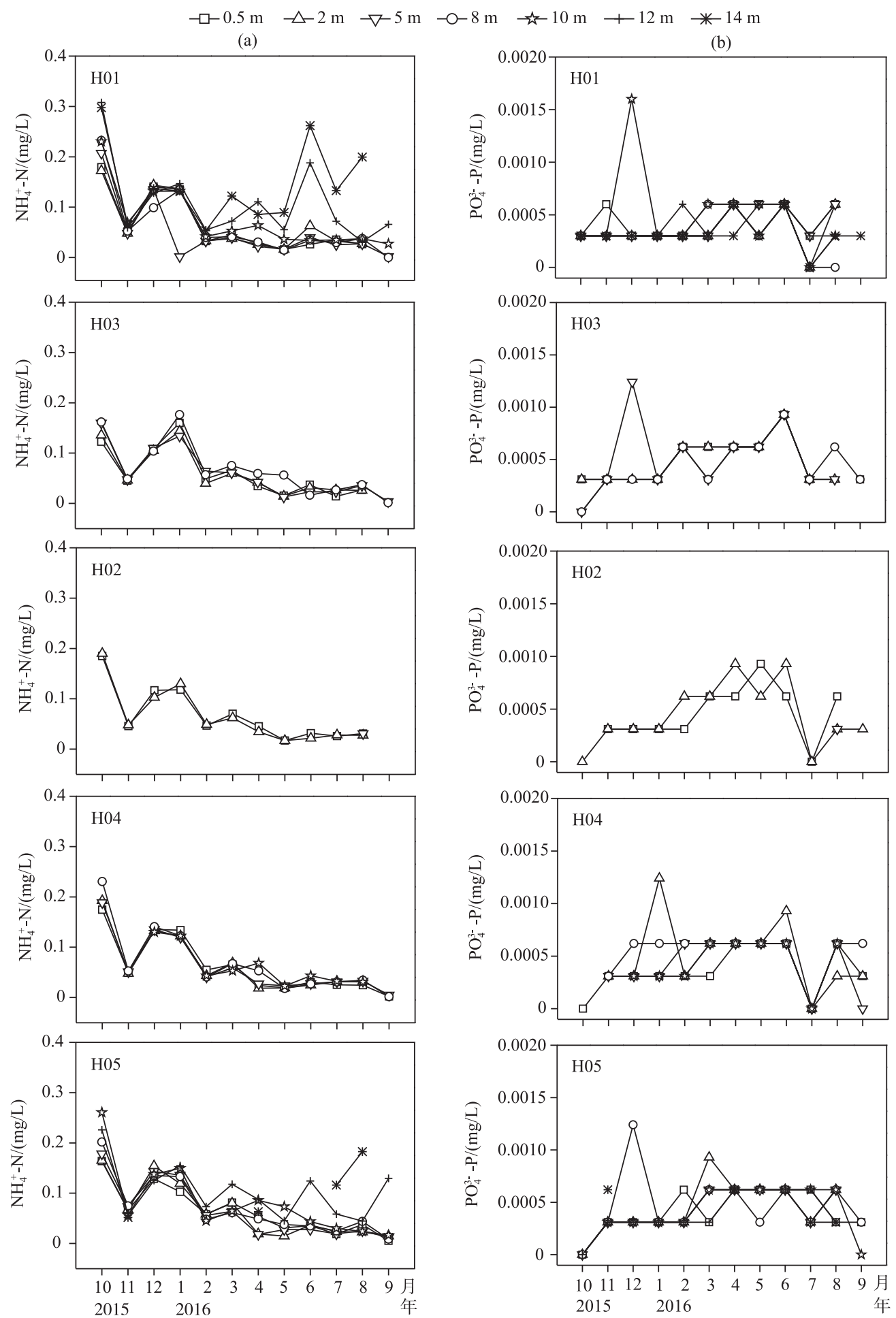

图 5 不同月份湖光岩玛珥湖水体中 $\mathrm{NH}_{4}^{+}-\mathrm{N}(\mathrm{a})$ 和 $\mathrm{PO}_{4}^{3}-\mathrm{P}(\mathrm{b})$ 浓度的垂直分布情况

Fig.5 The vertical distribution of $\mathrm{NH}_{4}^{+}-\mathrm{N}$ ( a ) and $\mathrm{PO}_{4}^{3}-\mathrm{P}$ (b) concentrations in the water of the Huguangyan Maar Lake in different months 
高(图 3). 夏季(7-9 月), 上层水体温度升高, 形成稳定的温跃层 (图 2), 水体的垂直交换较弱; 浅层水体 $(<10 \mathrm{~m})$ 由于浮游植物的消耗而导致营养盐浓度较低, 深层水体 $(>10 \mathrm{~m})$ 由于沉降的有机物消耗氧气进行 氧化分解而产生较多的营养盐 ${ }^{[4]}$ (图 4 图 6), 导致该时间段深层水体的浮游植物浓度较高 (图 3).

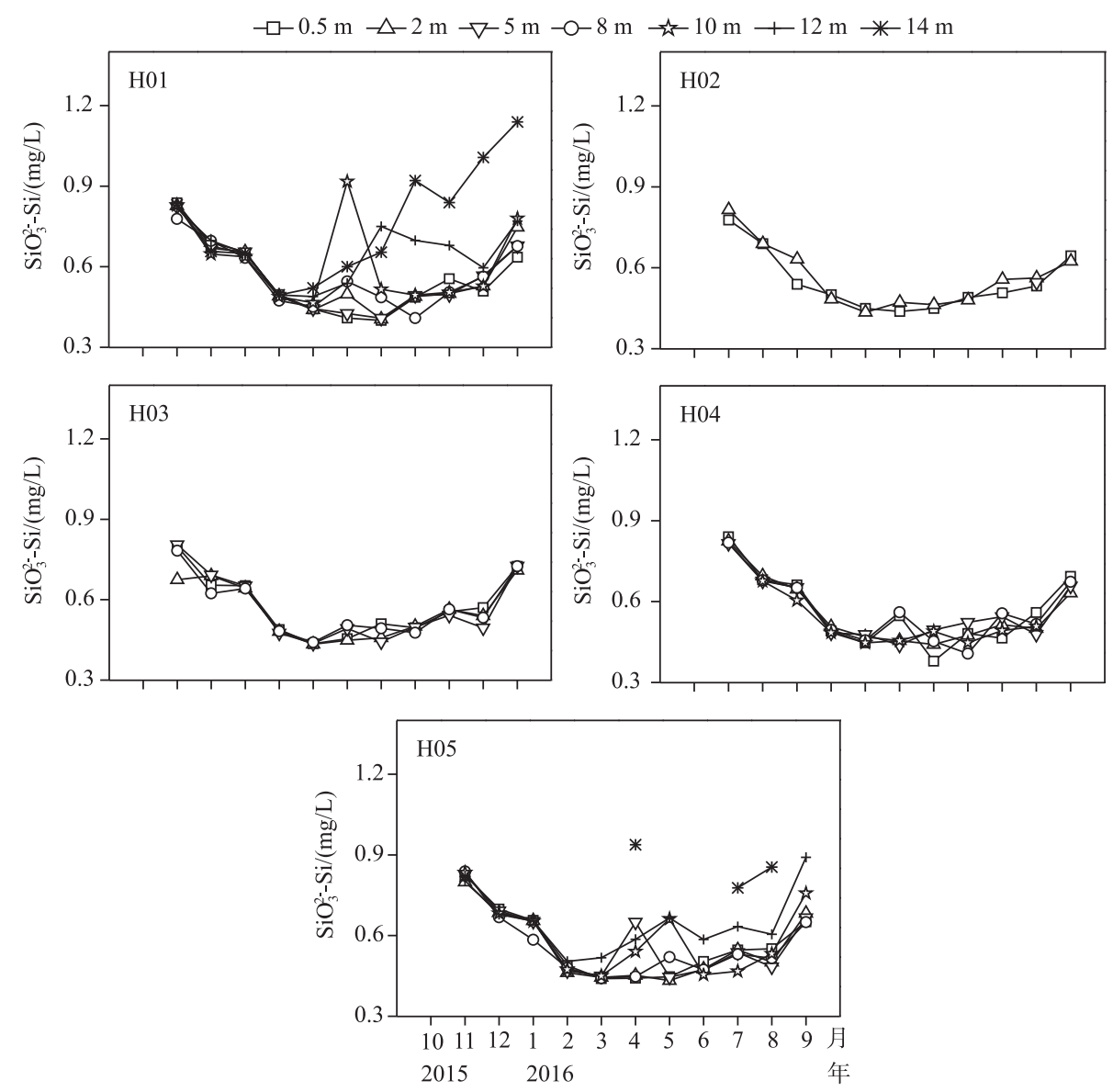

图 6 不同月份湖光岩玛珥湖水体中 $\mathrm{SiO}_{3}^{2-}-\mathrm{Si}$ 浓度的垂直分布情况

Fig.6 The vertical distribution of $\mathrm{SiO}_{3}^{2-}-\mathrm{Si}$ concentration in the water of the Huguangyan Maar Lake in different months

2.2.3 湖光岩玛珥湖表层水中营养盐的时间变化情况分析 夏季风期间, 水体层化,水体的垂直交换变差, 导 致深层水体 $(>10 \mathrm{~m}$ ) 营养盐的时间变化趋势与表层存在一定程度的差异 (图 4 图 6). 前文已对深层水体营 养盐浓度的变化做过分析, 为了解湖光岩玛珥湖表层水营养盐的时间变化原因, 下面仅对表层水中营养盐 的时间变化情况进行具体分析. 由于同一时间段不同站位间同水层的营养盐浓度差别不大, 不同站位表层 水营养盐的时间变化趋势相近 (图 4 图 6), 考虑到 H02 站位水深较浅, 图 4 图 6 中 H02 站位表层水营养 盐的时间变化趋势情况没有被深层水所掩盖, 因此接下来仅对 H02 表层水营养盐的时间变化情况进行具体 分析. 从图 4 图 6 给出的 $\mathrm{H} 02$ 站位营养盐的分布情况可以看出, 表层水中 $\mathrm{NO}_{3}^{-}-\mathrm{N}$ 浓度的时间变化趋势为单 峰, 它在 3 月最高, 在 10 月一次年 3 月呈增加趋势, 在 3-9 月呈降低趋势 (图 4a, $\mathrm{H} 02$ ); $\mathrm{NO}_{2}^{-}-\mathrm{N}$ 浓度的时间 变化规律不是很明显, 它在一年中的浓度都较低 (图 4b, H02); $\mathrm{NH}_{4}^{+}-\mathrm{N}$ 浓度从 10 月一次年 3 月总体呈下降趋 势, 而在 4-9 月都较低 (图 5a, $\mathrm{H} 02$ ) ; 同 $\mathrm{NO}_{2}^{-}-\mathrm{N}$ 相似, $\mathrm{PO}_{4}^{3-}-\mathrm{P}$ 浓度在一年中也较低, 没有明显的时间变化规 律 (图 $5 \mathrm{~b}, \mathrm{H} 02$ ); $\mathrm{SiO}_{3}^{2-}-\mathrm{Si}$ 浓度在 3 月份最低, 在 10 月一次年 3 月呈降低趋势, 而在 3-9 月呈增加趋势 (图 6 , 
H02).

对一年中 $\mathrm{H} 02$ 站位表层水中的营养盐及其他相关参数进行皮尔逊相关分析, 分析结果见表 2. 由表 2 可 知, 温度与溶解氧、Chl. $\mathrm{a} 、 \mathrm{NO}_{2}^{-}-\mathrm{N}$ 和 $\mathrm{NO}_{3}^{-}-\mathrm{N}$ 浓度均呈显著负相关, 与 $\mathrm{pH}$ 呈显著正相关; $\mathrm{pH}$ 与 $\mathrm{NO}_{2}^{-}-\mathrm{N}$ 和 $\mathrm{NO}_{3}^{-}-\mathrm{N}$ 浓度均呈显著负相关; Chl.a 浓度与 $\mathrm{NO}_{2}^{-}-\mathrm{N}$ 和 $\mathrm{NO}_{3}^{-}-\mathrm{N}$ 浓度均呈显著正相关; 溶解氧浓度与 $\mathrm{NO}_{3}^{-}-\mathrm{N}$ 浓度呈显著 正相关. 温度会对溶解氧的溶解度产生影响, 温度降低会导致溶解氧的溶解度升高 (图 2, H02 和图 4b, H02 所示, H02 站位表层水中溶解氧浓度在温度最低的 2 月最高), 因而温度与溶解氧浓度呈显著负相关 (表 2), 这一情况说明湖光岩表层水的溶解氧浓度随时间的变化受水体温度变化的影响明显. $\mathrm{NO}_{2}^{-}-\mathrm{N}$ 和 $\mathrm{NO}_{3}^{-}-\mathrm{N}$ 与 Chl. a 浓度均呈显著正相关, $\mathrm{NH}_{4}^{+}-\mathrm{N} 、 \mathrm{SiO}_{3}^{2-}-\mathrm{Si}$ 和 $\mathrm{PO}_{4}^{3-}-\mathrm{P}$ 与 $\mathrm{Chl}$. a 浓度的相关性不显著, 说明湖光岩玛珥湖表 层水中的 $\mathrm{NO}_{2}^{-}-\mathrm{N}$ 和 $\mathrm{NO}_{3}^{-}-\mathrm{N}$ 对浮游植物的生长起促进作用.

表 $2 \mathrm{H} 02$ 站位不同月份表层水中营养盐及其他参数之间的皮尔逊相关性

Tab.2 Pearson correlation analysis among nutrients and other related parameters in the surface water of the H02 station in different months

\begin{tabular}{cccccrrrr}
\hline 相关性 & $\mathrm{pH}$ & $\mathrm{Chl.a}$ & $\mathrm{DO}$ & $\mathrm{NO}_{3}^{-}-\mathrm{N}$ & $\mathrm{NO}_{2}^{-}-\mathrm{N}$ & $\mathrm{NH}_{4}^{+}-\mathrm{N}$ & $\mathrm{PO}_{4}^{3-}-\mathrm{P}$ & $\mathrm{SiO}_{3}^{2-}-\mathrm{Si}^{2}$ \\
\hline $\mathrm{T}$ & $0.775^{* *}$ & $-0.694^{*}$ & $-0.621^{*}$ & $-0.897^{* *}$ & $-780^{* *}$ & -0.152 & 0.158 & -0.152 \\
$\mathrm{pH}$ & 1 & -0.311 & -0.472 & $-0.710^{* *}$ & $-0.644^{*}$ & -0.083 & 0.030 & -0.223 \\
$\mathrm{Chl.a}$ & 1 & 0.474 & $0.583^{*}$ & $0.682^{*}$ & 0.029 & 0.013 & 0.145 \\
$\mathrm{DO}$ & & 1 & $0.660^{*}$ & 0.228 & 0.159 & -0.055 & $-0.594^{*}$ \\
$\mathrm{NO}_{3}^{-}-\mathrm{N}$ & & & 1 & $0.720^{* *}$ & -0.045 & 0.123 & 0.054 \\
$\mathrm{NO}_{2}^{-}-\mathrm{N}$ & & & & 1 & 0.240 & 0.106 & 0.443 \\
$\mathrm{NH}_{4}^{+}-\mathrm{N}$ & & & & & 1 & -0.551 & -0.216 \\
$\mathrm{PO}_{4}^{3-}-\mathrm{P}$ & & & & & & & 1 & 0.195 \\
$\mathrm{SiO}_{3}^{2-}-\mathrm{Si}$ & & & & & & & & \\
\hline
\end{tabular}

* 表示显著性水平 $P<0.05 ; * *$ 表示显著性水平 $P<0.01$.

$\mathrm{NO}_{3}^{-}-\mathrm{N}$ 浓度从 10 月一次年 3 月份呈增加趋势, 原因可能是该时间段水体中有机质矿化分解产生营养盐 的速率高于浮游植物同化吸收营养盐的速率, 使得水体中的硝酸盐产生累积, 又由于该时间段盛行冬季风, 水体垂直混合较均匀 (图 2), 因而导致表层水中 $\mathrm{NO}_{3}^{-}-\mathrm{N}$ 浓度呈增加趋势. 3 月以后, 水体中浮游植物的同化 作用可能强于有机质的矿化分解作用, 导致 $\mathrm{NO}_{3}^{-}-\mathrm{N}$ 浓度降低. 3 月以后水体出现层化, 浅层水体营养盐消耗 后得不到有效补充, 这对该时间段 $\mathrm{NO}_{3}^{-}-\mathrm{N}$ 浓度的降低也有一定的贡献. 表层水中 $\mathrm{NH}_{4}^{+}-\mathrm{N}$ 浓度与其他所测参 数没有表现出明显的相关性, 但从 $\mathrm{NH}_{4}^{+}-\mathrm{N}$ 和 Chl. a 浓度的时间变化趋势来看 (图 3, 图 5a), $\mathrm{NH}_{4}^{+}-\mathrm{N}$ 浓度从 10 月一次年 5 月持续降低可能与浮游植物的吸收利用有关. 杨柳等 ${ }^{[23]}$ 和张国维 ${ }^{[10]}$ 对湖泊中浮游植物吸收营养 盐的研究发现, 浮游植物群落对 $\mathrm{NH}_{4}^{+}-\mathrm{N}$ 具有较高的吸收潜力, 这也进一步说明了氨浓度的降低与浮游植物 的利用有紧密关系. 另外值得注意的是, 在 $\mathrm{NH}_{4}^{+}-\mathrm{N}$ 浓度降低的时间段 (10 月一次年 3 月), $\mathrm{NO}_{3}^{-}-\mathrm{N}$ 浓度呈增 加趋势 (图 4a, H02), 这可能显示冬季风期间, 水体硝化作用明显, 硝化导致水中的 $\mathrm{NH}_{4}^{+}-\mathrm{N}$ 不断向 $\mathrm{NO}_{3}^{-}-\mathrm{N}$ 转 化 ${ }^{[24]}$. 夏季风期间, $\mathrm{H} 02$ 站位表层水中 $\mathrm{NH}_{4}^{+}-\mathrm{N}$ 和 $\mathrm{NO}_{3}^{-}-\mathrm{N}$ 浓度都较低 (图 4 和图 5a), 这主要是受浮游植物的 充分吸收及水体层化导致浅层水体的营养盐得不到有效补充的影响.

由于表层水中 $\mathrm{SiO}_{3}^{2-}-\mathrm{Si}$ 浓度与其他所分析的参数都不显著相关, 所以由相关分析无法判断表层水中 $\mathrm{SiO}_{3}^{2-}-\mathrm{Si}$ 浓度的变化原因. 影响 $\mathrm{SiO}_{3}^{2-}-\mathrm{Si}$ 浓度变化的因素可能有降雨、浮游植物吸收以及有机质的矿化分解. 冬季风期间, 沉积物有机质氧化分解可产生较多的营养盐, 且水体垂直混合较均匀 (图 2), 导致该时间段 $\mathrm{SiO}_{3}^{2-}-\mathrm{Si}$ 浓度较高 (图 6, $\mathrm{H} 02$ ). 由 11 月一次年 4 月, $\mathrm{SiO}_{3}^{2-}-\mathrm{Si}$ 浓度持续降低, 这可能与浮游植物的吸收利用有 关. 在 5-9 月 $\mathrm{SiO}_{3}^{2-}-\mathrm{Si}$ 浓度持续升高, 这可能与强降雨导致较多的 $\mathrm{SiO}_{3}^{2-}-\mathrm{Si}$ 进入湖泊有关 ${ }^{[19]}$. 从 12 月一次 年 5 月 Chl.a 浓度相对较高 (图 3), 这期间的 $\mathrm{SiO}_{3}^{2-}-\mathrm{Si}$ 浓度持续降低 (图 6, H02), 这可能说明浮游植物不断 吸收导致 $\mathrm{SiO}_{3}^{2-}-\mathrm{Si}$ 浓度持续降低. 图 7 为调查期间湖光岩玛珥湖降雨量随时间的变化情况. 6-9 月 $\mathrm{SiO}_{3}^{2-}-\mathrm{Si}$ 浓度持续增高(图 6,H02), 在这一时间段, Chl.a 浓度较低(图 3), 而降雨量较大(图 7), 因而可能导致较多 
的 $\mathrm{SiO}_{3}^{2-}-\mathrm{Si}$ 进人湖水而产生累积(图 6,H02). 因此可以推断, 湖光岩玛珥湖表层水中 $\mathrm{SiO}_{3}^{2-}-\mathrm{Si}$ 浓度的变化受 有机质分解、浮游植物吸收和降雨的综合影响.

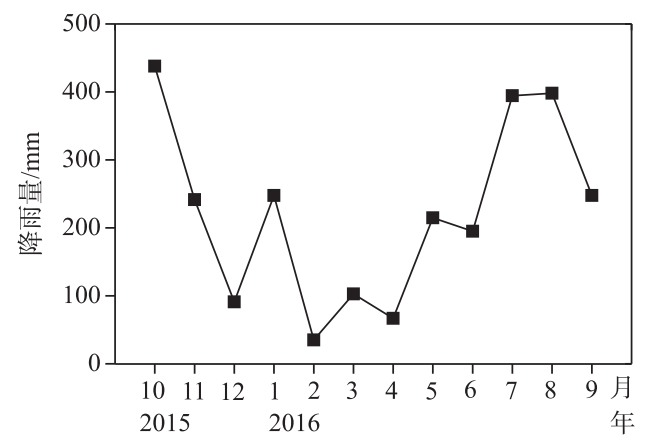

图 7 调查期间湖光岩玛珥湖的降雨量随时间的变化情况

Fig.7 The temporal variations of rainfall in the Huguangyan Maar Lake during the investigation period

\section{3 湖光岩玛珥湖水体中的营养盐与我国其他湖泊的对比情况}

湖光岩玛珥湖表层水及我国其他湖泊水体中营养盐的浓度及组成情况见表 3 . 与表 3 给出的我国其他 湖泊相比, 湖光岩玛珥湖表层水中 $\mathrm{NO}_{3}^{-}-\mathrm{N} 、 \mathrm{NO}_{2}^{-}-\mathrm{N} 、 \mathrm{NH}_{4}^{+}-\mathrm{N}$ 和 $\mathrm{PO}_{4}^{3-}-\mathrm{P}$ 浓度相对较低, 而 $\mathrm{SiO}_{3}^{2-}-\mathrm{Si}$ 浓度相对较 高, 这可能与湖光岩玛珥湖的构造以及受人类活动影响较小有关. 湖泊中 $\mathrm{NO}_{3}^{-}-\mathrm{N} 、 \mathrm{NO}_{2}^{-}-\mathrm{N} 、 \mathrm{NH}_{4}^{+}-\mathrm{N}$ 和 $\mathrm{PO}_{4}^{3-}-\mathrm{P}$ 的来源主要是人为来源, 如工业、农业废水及生活污水的排放 ${ }^{[5,6,8,26]}$. 湖光岩玛珥湖四面封闭, 无出人水口, 受人类活动影响较小. 此外, 玛珥湖水体中的 $\mathrm{PO}_{4}^{3-}-\mathrm{P}$ 被浮游植物充分消耗, 使得水中的 $\mathrm{PO}_{4}^{3-}-\mathrm{P}$ 浓度长期处 于较低值, 导致水体表现为较强的磷限制 (表 1). 湖光岩玛珥湖四面为火山岩, 火山岩含有丰富的硅, 降雨

表 3 湖光岩玛珥湖表层水的营养盐与我国其他湖泊营养盐的浓度和组成情况

Tab.3 The concentrations and composition of nutrients in the surface water of the Huguangyan Maar Lake and other lakes in China

\begin{tabular}{|c|c|c|c|c|c|c|c|c|c|c|}
\hline 湖泊 & 季节 & $\begin{array}{l}\mathrm{NO}_{3}^{-}-\mathrm{N} / \\
(\mathrm{mg} / \mathrm{L})\end{array}$ & $\begin{array}{l}\mathrm{NO}_{2}^{-}-\mathrm{N} / \\
(\mathrm{mg} / \mathrm{L})\end{array}$ & $\begin{array}{l}\mathrm{NH}_{4}^{+}-\mathrm{N} / \\
(\mathrm{mg} / \mathrm{L})\end{array}$ & $\begin{array}{c}\mathrm{SiO}_{3}^{2-}-\mathrm{Si} / \\
(\mathrm{mg} / \mathrm{L})\end{array}$ & $\begin{array}{c}\mathrm{PO}_{4}^{3-}-\mathrm{P} / \\
(\mathrm{mg} / \mathrm{L})\end{array}$ & $\begin{array}{c}\mathrm{Si}: \mathrm{P} \\
\text { (摩尔比) }\end{array}$ & $\begin{array}{c}\mathrm{Si}: \mathrm{N} \\
\text { (摩尔比) }\end{array}$ & $\begin{array}{c}\mathrm{N}: \mathrm{P} \\
\text { (摩尔比) }\end{array}$ & $\begin{array}{l}\text { 参考 } \\
\text { 文献 }\end{array}$ \\
\hline \multirow[t]{2}{*}{ 太湖 } & 冬季 & $0.1 \sim 2.2$ & ND & $0.07 \sim 0.99$ & $0.1 \sim 0.6$ & $0.004 \sim 0.008$ & $6 \sim 96$ & $0.03 \sim 0.23$ & $80 \sim 1270$ & {$[7]$} \\
\hline & 夏季 & $0.2 \sim 2.9$ & $0.1 \sim 2.5$ & $\mathrm{ND} \sim 1.01$ & $0.2 \sim 0.8$ & $0.01 \sim 0.1$ & $4 \sim 20$ & $0.03 \sim 0.23$ & $50 \sim 310$ & \\
\hline 东平湖 & 冬季 & 0.423 & 0.01 & 0.131 & - & - & - & - & - & {$[8]$} \\
\hline \multirow[t]{2}{*}{ 鄱阳湖 } & 秋季 & \multicolumn{2}{|c|}{$0.66^{\mathrm{a}}$} & 0.4 & - & 0.017 & - & - & - & {$[6]$} \\
\hline & 夏季 & \multicolumn{2}{|c|}{$0.92^{\mathrm{a}}$} & 0.12 & - & 0.027 & - & - & - & \\
\hline \multirow[t]{2}{*}{ 洞庭湖 } & 冬季 & 0.45 & - & 0.23 & - & - & - & - & 32.7 & {$[27]$} \\
\hline & 夏季 & 0.63 & - & 0.3 & - & - & - & - & 39 & \\
\hline 天目湖 & - & - & - & - & - & - & - & - & 22 & {$[28]$} \\
\hline 滇池 & 夏季 & 0.41 & - & 0.38 & - & - & - & - & $<7$ & {$[26]$} \\
\hline 青山湖 & - & - & - & - & - & - & - & - & $1.0 \sim 6.7$ & {$[5]$} \\
\hline 瑶湖 & - & - & - & - & - & - & - & - & $1.8 \sim 5.8$ & {$[5]$} \\
\hline 军山湖 & - & - & - & - & - & - & - & - & $3.2 \sim 56.6$ & {$[5]$} \\
\hline 岱海湖 & - & - & - & - & - & - & - & - & 12.6 & [29] \\
\hline 湖光岩 & 秋季 & 0.018 & 0.0006 & 0.100 & 0.742 & 0.0003 & $534 \sim 3000$ & $1.44 \sim 23.1$ & $87 \sim 1473$ & 本研究 \\
\hline \multirow[t]{3}{*}{ 玛珥湖 } & 冬季 & 0.050 & 0.0007 & 0.101 & 0.601 & 0.0004 & & & & 本研究 \\
\hline & 春季 & 0.047 & 0.0006 & 0.041 & 0.446 & 0.0006 & & & & 本研究 \\
\hline & 夏季 & 0.009 & 0.0003 & 0.028 & 0.520 & 0.0005 & & & & 本研究 \\
\hline
\end{tabular}

$\mathrm{ND}$ 表示低于检测限; $\mathrm{a}$ 为 $\mathrm{NO}_{3}^{-}-\mathrm{N}$ 和 $\mathrm{NO}_{2}^{-}-\mathrm{N}$ 的加和; 一表示未检测. 
可能导致岩石、土壤风化产生的颗粒及易溶解的物质随雨水冲刷, 从而导致含较高浓度 $\mathrm{SiO}_{3}^{2-}-\mathrm{Si}$ 的雨水进人 水体, 造成湖光岩水体中 $\mathrm{SiO}_{3}^{2-}-\mathrm{Si}$ 浓度明显高于其他湖泊 ${ }^{[25]}$. 前文也从 $\mathrm{SiO}_{3}^{2-}-\mathrm{Si}$ 浓度的时间变化情况推断出 夏季强降雨对湖光岩玛珥湖水体中的 $\mathrm{SiO}_{3}^{2-}-\mathrm{Si}$ 浓度有一定的影响 (2.2.3 节) .

与表 3 给出的其他湖泊水体中营养盐的季节变化相比, 冬季湖光岩玛珥湖表层水中 $\mathrm{NO}_{3}^{-}-\mathrm{N} \mathrm{NO}_{2}^{-}-\mathrm{N}$ 、 $\mathrm{NH}_{4}^{+}-\mathrm{N}$ 和 $\mathrm{SiO}_{3}^{2-}-\mathrm{Si}$ 的浓度明显高于夏季, 而太湖 ${ }^{[7]}$ 和洞庭湖 ${ }^{[27]}$ 水体中营养盐浓度在冬季处于较低值, 这可 能与湖光岩玛珥湖处于东亚季风区域有关. 如前文所述 (2.2.2 节), 湖光岩玛珥湖水中的营养盐垂直分布受 季风影响较明显, 冬季风期间, 水体扰动强烈, 上下层水体混合较为均匀 (图 2), 使得表层营养盐得到有效补 充 (图 4 图 6); 夏季受温跃层影响, 营养盐得不到有效补充, 表层营养盐被大量消耗, 呈现出较低的浓度 (图 2, 图 4 图 6).

\section{3 结论}

1) 湖光岩玛珥湖水中的 DIN 以 $\mathrm{NH}_{4}^{+}-\mathrm{N}$ 为主, 其次是 $\mathrm{NO}_{3}^{-}-\mathrm{N}, \mathrm{NO}_{2}^{-}-\mathrm{N}$ 所占比例最低. 与我国其他湖泊相 比, 湖光岩玛珥湖水中的 $\mathrm{SiO}_{3}^{2-}-\mathrm{Si}$ 浓度较高, $\mathrm{NO}_{3}^{-}-\mathrm{N} 、 \mathrm{NO}_{2}^{-}-\mathrm{N} 、 \mathrm{NH}_{4}^{+}-\mathrm{N}$ 和 $\mathrm{PO}_{4}^{3-}-\mathrm{P}$ 浓度较低, 这可能与湖光岩玛 珥湖的构造以及受人类活动影响较小有关. 湖光岩玛珥湖水中营养盐的垂直分布在冬季风和夏季风期间差 异明显, 冬季风期间水体垂直交换较强, 营养盐垂直分布均匀, 夏季风期间, 水体层化明显, 导致浅层水体 $(<10 \mathrm{~m})$ 营养盐浓度较低,深层水体 $(>10 \mathrm{~m})$ 营养盐浓度较高.

2) 冬季风期间有机质的矿化分解、水体的垂直混合、 $\mathrm{NH}_{4}^{+}-\mathrm{N}$ 的硝化均可能对湖光岩玛珥湖表层水中 $\mathrm{NO}_{3}^{-}-\mathrm{N}$ 浓度在该时间段的升高有贡献; 夏季风期间水体的层化、浮游植物的消耗均可能对 $\mathrm{NO}_{3}^{-}-\mathrm{N}$ 浓度的降 低有贡献. $\mathrm{NH}_{4}^{+}-\mathrm{N}$ 浓度从 10 月一次年 5 月持续降低可能与浮游植物的吸收利用及 $\mathrm{NH}_{4}^{+}-\mathrm{N}$ 的硝化有关. $\mathrm{SiO}_{3}^{2-}-\mathrm{Si}$ 的浓度从 11 月一次年 5 月持续降低, 可能与浮游植物较强的吸收利用及降雨输人较少有关, 5-9 月 持续升高可能与浮游植物吸收利用的量较低及降雨输人量加大有关.

\section{4 参考文献}

[ 1 ] Zhu GW, Jin YW, Ren J et al. Characteristics of diatom blooms in a reservoir-water supply area and the countermeasures in Taihu Basin, China. J Lake Sci, 2016, 28(1) : 9-21. DOI: 10.18307/2016.0102. [ 朱广伟, 金颖薇, 任杰等. 太湖 流域水库型水源地硅藻水华发生特征及对策分析. 湖泊科学, 2016, 28(1): 9-21.]

[ 2 ] Dehairs F, Fripiat F, Cavagna AJ et al. Nitrogen cycling in the Southern Ocean Kerguelen Plateau area: Evidence for significant surface nitrification from nitrate isotopic compositions. Biogeosciences Discussions, 2014, 11(9): 1459-1482.

[ 3 ] Guo Y, Yu G. Simulations on historical nutrient changes of typical lakes in the middle and lower reaches of Yangtze River, China. J Lake Sci, 2016, 28(4) : 875-886. DOI: 10.18307/2016.0422. [ 郭娅, 于革. 长江中下游典型湖泊营养盐历 史变化模拟. 湖泊科学, 2016, 28(4):875-886.]

[ 4 ] Li YW, Hu YY, Chen SM. Distribution and influence factors of nutrients in the North Yellow Sea in summer and autumn. China Environmental Science, 2013, 33(6) : 1060-1067. [李延伟, 胡芗芗, 陈淑梅. 夏、秋季北黄海营养盐的时空分 布特征及其影响机制. 中国环境科学, 2013, 33(6): 1060-1067.]

[ 5 ] Kuang WM, Zhang M, Zhang JM et al. Comparative limnological study on annual dynamic pattern of nutrients in water column of three suburb lakes adjacent to Lake Poyang. J Lake Sci, 2016, 28(6) : 1293-1305. DOI: 10.18307/2016.0615. [匡武名, 张萌, 张金美等. 鄱阳湖外围湖泊水体营养波动周年特征的比较湖沼学研究. 湖泊科学, 2016, 28(6): 1293-1305.

[ 6 ] Liu X, Liu BG, Chen YW et al. Responses of nutrients and chlorophyll a to water level fluctuations in Poyang Lake. Environmental Science, 2016, 37(6) : 2141-2148. [刘霞, 刘宝贵, 陈宇炜等. 鄱阳湖浮游植物叶绿素 a 及营养盐浓度对 水位波动的响应. 环境科学, 2016, 37(6): 2141-2148.]

[ 7 ] Li J, Liu CQ, Wang SL et al. Seansonal variations in composition and distribution of dissolved nutrients in the water column of Taihu Lake, China. Earth and Environment, 2005, 33(1): 63-67. [李军, 刘丛强, 王仕禄等. 太湖水体溶解 营养盐 $(\mathrm{N} 、 \mathrm{P} 、 \mathrm{Si})$ 的冬、夏二季变化特征及其与富营养化的关系. 地球与环境, 2005, 33(1): 63-67.]

[ 8 ] Luo WL, Tian J, Zhang J et al. Characterization of nutrient pollution of Dongping Lake winter water and its quality assess- 
ment. Transaction of Oceanology and Limnology, 2016, (2) : 8-16. [罗文否, 田娟, 张菊等. 东平湖冬季水体营养盐 污染特征及水质评价. 海洋湖沼通报, 2016, (2) : 8-16.]

[ 9 ] Wu P, Deng JM, Qin BQ et al. Effects of enhanced water temperature and nutrient concentration on algal growth in winter and spring season in Lake Taihu, China. Research of Environmental Sciences, 2013, 26(10): 1064-1071. [吴攀, 邓建 明, 秦伯强等. 水温和营养盐增加对太湖冬、春季节藻类生长的影响. 环境科学研究, 2013, 26(10) : 1064-1071.]

[10] Zhang GW. Studies on dissovled nitrogen, phytoplankton and nitrogen uptake by phytoplankton in Huguangyan Maar Lake [Dissertaion]. Zhanjiang: Guangdong Ocean University, 2014. [张国维. 湖光岩玛珥湖溶解态氮与浮游植物及其氮 吸收的研究 [ 学位论文]. 湛江: 广东海洋大学, 2014.]

[11] Funiciello R, Giordano GI, De Rita D. The Albano Maar lake (Colli Albani Volcano, Italy) : recent volcanic activity and evidence of pre-Roman Age catastrophic lahar events. Journal of Volcanology and Geothermal Research, 2003, 123(1) : 43-61.

[12] Zolitschka B, Brauer A, Negendank JFW et al. Annually dated late Weichselian continental paleoclimate record from the Eifel, Germany. Geology, 2000, 28 (9) : 783-786.

[13] Sirocko F, Knapp H, Dreher F et al. The ELSA-Vegetation-Stack: Reconstruction of Landscape Evolution Zones (LEZ) from laminated Eifel maar sediments of the last 60,000 years. Global and Planetary Change, 2016, 142: 108-135.

[14] Zhang CX, Sun SL, Xie SY et al. The phytoplankton of the Huguangyan Maar Lake. Acta Hydrobiologica Sinica, 2008,32 (5) : 620-630. [张才学, 孙省利, 谢少英等. 湖光岩玛珥湖的浮游植物. 水生生物学报, 2008, 32(5):620-630.]

[15] Guo QR. Comparison of genetic diversity of total planktonic bacteria and active planktonic bacteria in Huguangyan Maar Lake in summer[Dissertation]. Zhanjiang: Guangdong Ocean University, 2011. [ 郭倩茹. 夏季湖光岩玛珥湖浮游细菌 和浮游活性菌遗传多样性的比较 [学位论文]. 湛江: 广东海洋大学, 2011.]

[16] Zhang GW, Huang XH, Li CL et al. Correlationa analysis between chlorophyll-a and water quality indices in Huguangyan Maar Lake and its eutrophication evaluation. Journal of Guangdong Ocean University, 2015, 35(1): 69-75. [张国维, 黄 翔鹄, 李长玲等. 湖光岩玛珥湖叶绿素 a 与水质因子的相关性分析及富营养化评价. 广东海洋大学学报, 2015, 35 (1) : 69-75.]

[17] Bai Y, Ouyang TP, Jia GD. Late Holocene human activity inferred from sedimentary n-Alkanes and their carbon isotope in the Huguangyan Maar Lake. Tropical Geography, 2014, 34(2): 156-163. [柏杨, 欧阳婷萍, 贾国东. 湖光岩玛珥湖晚 全新世人类活动的叶蜡烷烃及其碳同位素沉积记录. 热带地理, 2014, 34(2) : 156-163.]

[18] Jin XC, Tu QY eds. Specification for lake eutrophication survey. Beijing: China Environmental Science Press, 1990. [ 金 相灿，屠清瑛. 湖泊富营养化调查规范. 北京: 中国环境科学出版社，1990.]

[19] Editorial board of the State Environmental Protection Administration of Water and Wastewater Monitoring and Analysis Methods ed. Determination methods for examination of water and wastewater. Beijing: China Environmental Science Press, 2002. [ 国家环境保护总局《水和废水监测分析方法》编委会. 水和废水监测分析方法. 北京: 中国环境科学出版 社, 2002.]

[20] Zhao W ed. Aquatic biology. Beijing: China Agriculture Press, 2005: 509. [ 赵文. 水生生物学. 北京: 中国农业出版 社, 2005: 509.]

[21] Justić D, Rabalais NN, Turner RE et al. Changes in nutrient structure of river-dominated coastal waters: stoichiometric nutrient balance and its consequences. Estuarine Coastal \& Shelf Science, 1995, 40(3) : 339-356.

[22] Zhou FX, Gao XL, Zhang Y et al. Potential mobility of inorganic nutrients and its controls at the sediment-water interface in the main path of Kuroshio Current off eastern Taiwan. Marine Pollution Bulletin, 2017, 119: 270-276.

[23] Yang L, Zhang M, Liu ZW. Uptake of various forms of nitrogen by phytoplankton community in spring in Lake Taihu. $J$ Lake Sci, 2011, 23(4) : 605-611. DOI:10.18307/2011.0417. [ 杨柳, 章铭, 刘正文. 太湖春季浮游植物群落对不同 形态氮的吸收. 湖泊科学, 2011, 23(4): 605-611.]

[24] Lan SH, Huang N, Wu PJ. Aerobic nitrification of ammonia nitrogen under high organic concentration. Chinese Journal of Environmental Engineering, 2017, 11(1) : 273-277. [兰善红, 黄娜, 吴鹏举. 高有机物浓度下氨氮的好氧硝化. 环 境工程学报, 2017, 11(1): 273-277.]

[25] Chen FJ, Chen CQ, Zhou FX et al. Nutrients in atmospheric wet deposition in the Zhanjiang Bay. China Environmental 
Science, 2017, 37(6) : 2055-2063. [陈法锦, 陈淳青, 周凤霞等. 湛江湾大气湿沉降中营养盐的研究. 中国环境科 学, 2017, 37(6): 2055-2063.]

[26] Yu LY, Yang H, Huang CC et al. Characteristic of nitrogen and phosphorous pollution in Lake Dianchi and its inflow rivers in summer. J Lake Sci, 2016, 28(5) : 961-971. DOI:10.18307/2016.0505. [余丽燕, 杨浩, 黄昌春等. 夏季滇池 和人滇河流氮、磷污染特征. 湖泊科学, 2016, 28(5): 961-971.]

[27] Wang Y, Jiang X, Li YF et al. Spatial and temporal distribution of nitrogen and phosphorus and nutritional characteristics of water in Dongting Lake. Research of Environmental Sciences, 2014, 27(5): 484-491. [王岩, 姜霞, 李永峰等. 洞庭 湖氮磷时空分布与水体营养状态特征. 环境科学研究, 2014, 27(5) : 484-491.]

[28] He RR, Gao YX, Wang F et al. Spatial-temporal distribution of nutrients and its causation in Tianmu Lake, China. Journal of Agro-Environmental Sciences, 2009, 28(2) : 353-360. [贺冉冉, 高永霞, 王芳等. 天目湖水体与沉积物中营养 盐时空分布及成因. 农业环境科学学报, 2009, 28(2): 353-360.]

[29] Gao XD. Environmental geochemical characteristics of nutrient in Daihai Lake[Dissertation]. Huhhot: Inner Mongolia University, 2006. [高兴东. 岱海湖泊营养盐的环境地球化学特征研究 [学位论文]. 呼和浩特: 内蒙古大学, 2006.] 